\title{
THE TOXIC AND ANTIGENIC PROPERTIES OF BACTERIUM WELCHII.*
}

EUGENE F. M C CAMPBELL.

(From the Pathological Laboratory of the University of Chicago and the Bacteriological Laboratory of Ohio State University.)

INTRODUCTION.

Bacterium welchii (Migula), or Bacillus aerogenes capsulatus (Welch), was discovered in I89I by Professor Welch in the blood and tissues of a tuberculous person who had died of hemorrhage from the rupture of an aortic aneurism. The entire body was emphysematous and distended with gas. Subsequently this bacillus has been isolated in many pathological conditions, among which may be mentioned emphysematous gangrene and gaseous phlegmons of various tissues following injuries, surgical operations (herniotomy, nephrectomy, urethrotomy, appendectomy, amputations, etc.), salt infusions, hypodermic injections, and cholelithiasis.

It has also been found in emphysema of the fetus, puerperal eclampsia, physometra, emphysema of the uterine wall, puerperal gas sepsis, urethral stricture with cystitis, emphysema of the bladder, interstitial emphysema of the gastro-intestinal wall, pneumoperitonitis with or without perforation, pneumonia and pulmonary gangrene, and in meningitis.

Herter ${ }^{1}$ has suggested that certain anemias, especially in children, may be associated with a chronic invasion of the intestinal tract by B. welchii.

In the light of the seeming increasing importance of $B$. welchii, it was deemed desirable to investigate the immunological relations of this bacterium.

As stated, $B \cdot$ welchii was discovered in $18 \mathrm{gI}$, the report of the discovery being published by Welch and Nuttall in 1892. Early in January, I893, E. Fraenkela described the same organism which he named Bacillus phlegmones emphysematosae because of its isolation from gaseous phlegmons. This work was followed by a more complete report of his studies in a monograph, "Ueber Gasphlegmonen." The same

* Received for publication June 24, roog.

I Jour. Biol. Chem., 1906, 2, p. 3 .

2 Centralbl. f. Bakt., 1893, 13, P. I3. 
bacterium has been described by other European investigators who ignored the American work. Thus B. enteritidis sporogenes (Klein), ${ }^{\mathrm{C}}$ B. perfringens (Veillon and Zuber), ${ }^{2}$ Granulo-bacillus saccharobutyricus immobilis (Schattenfroth and Grassberger), $3 B$. anaerobie cryptobutyricus (Achalme), 4 B. cadaveris butyricus (Buday), 5 Bacillus of Cesaris-Demel, ${ }^{6}$ and $B$. emphysematis vaginae (Lindenthal) 7 are undoubtedly $B$. welchii.

Welch in $1900^{8}$ and E. Fraenkel in I $902^{9}$ gave excellent and complete résumés of the literature. It is therefore necessary to refer only to a few observations made since their reports, and to discuss only certain points relative to the pathological changes produced by the organism. Of work dealing with certain phases of the immunity to and infection with $B$. welchii, that of Kamen, "Zur Aetiologie der Gasphlegmon,".。 dealing with toxins, agglutinins, etc., and of Passini, "Ueber Giftstoffe in den Kulturen des Gasphlegmon-Bazillus," + are noteworthy. Werner 2 discusses the agglutinins for the gas bacillus.

Falkner 3 deals with certain phases of the production of foamy organs, and Ghon and Sachs 4 with some of the gross pathological aspects of infections with $B$. welchii. The work of Herter 5 on the bacterial processes in the intestine in advanced anemias and the relation of $B$. welchii to them, and the studies of Rettger ${ }^{6}$ on intestinal putrefaction and the relation of $B$. welchii to the various processes, are also worthy of consideration. Noguchi'7 has reported on "Sporulation in the Group of Bacillus aerogenes capsulatus" and Legros ${ }^{8}$ on "Recherches histologiques sur les gangrenes gazeuses aigues." A few other observations of interest will be mentioned under the section on pathology.

\section{ISOLATION AND CHARACTERISTICS.}

Habitat. $-B$. welchii is widely distributed, occurring most universally in the intestinal tract of man and animals, in sewage, soil, water, milk, etc. Dolby ${ }^{9}$ found it in 69 of 250 blank cartridge wads, probably introduced in the ingredients used in manufacture.

Method of Isolation.-The method of isolation essentially suggested by Welch, with some slight modifications, is as follows: One gram of soil is shaken in sterile $\mathrm{NaCl}$ solution ( 0.85 per cent) and inoculated into sterile neutral litmus milk tubes

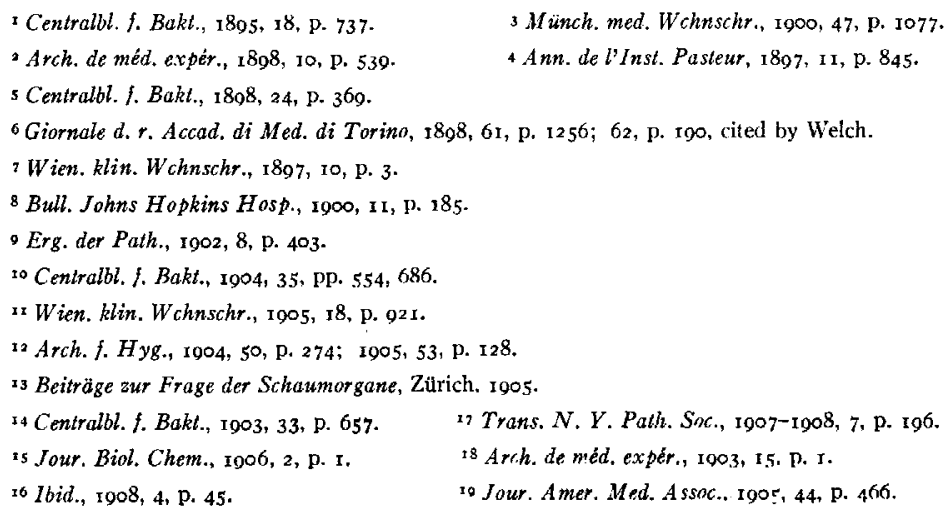


which are covered with $25 \mathrm{~mm}$. of neutral paraffin oil for the purpose of securing anaerobiosis, and then incubated for 24 hours at $37^{\circ} \mathrm{C}$. At the end of this time the milk in the tube is coagulated and shows acid and gas (see milk-infra). A sub-culture is made in a second litmus milk tube under oil and incubated for 12 hours in order to prevent the possible overgrowth of other bacteria. At the end of this time the milk usually shows coagulation, acid, and gas production as in the first instance ("stormy fermentation"); 0.5 c.c. of the whey in the sub-culture is then injected into the posterior auricular vein of a rabbit. In three or four minutes the animal is killed by a blow on the head and the body incubated at $37^{\circ} \mathrm{C}$. for 8 to to hours, at the end of which time the abdomen is markedly distended with gas. When ignited this gas explodes and burns with a hydrogen flame. The thorax of the animal is carefully opened and cultures made from the heart blood in dextrose broth covered by neutral paraffin oil. In from 8 to 24 hours the culture tubes show a marked cloudiness, abundant gas production, and, in most instances, an odor of butyric acid. With this technic a pure culture of $B$. welchii is usually secured.

Characteristics of $B$. welchii.-This bacterium is an obligate anaerobe. Typical cultures show the following characteristics. It is a non-motile, rod-shaped bacterium, from 3 to $6 \mu$ long. I have noted shorter forms $(2-3 \mu)$. Occasionally it may be quite broad and plump but usually it is from $5-8 \mu$ in width. It frequently grows in chains but is often single and in pairs. In the fluids and organs of the body capsules are usually produced, but seldom on artificial media. Spores are often produced, but in some strains spore production does not seem to occur. The spores usually appear in the center of the rod, altho occasionally at the end, and markedly increase the diameter of the cells at these points. The spores stain with comparative ease by ordinary methods.

The asporogenous type of $B$. welchii may be transformed into the sporogenous type in various ways (Passini).' Grassberger inoculated sterile beef muscle with a dextrose agar culture incubated in a Buchner tube. Egg-white with broth may be used. Sporulation once started may be kept up by continuous transference on dextrose agar. Often the presence of alkalies will induce spore formation. Sporebearing cultures on injection into susceptible animals of ten become asporogenous.

$B$. welchii stains by all the anilin dyes and by Gram's method.

Agar and gelatin plates (plain) show round, flat, greyish-white, smooth and semitranslucent colonies on the surface (1.5-4 mm.). Microscopically these colonies usually show a definite center or nucleus surrounded by a granular growth. The colonies are often "woolly" in appearance, similar to those of B. tetani (Muir and Ritchie). Deep colonies are round and white. Slope agar shows yellowish-white and extremely thin growth. Glucose agar and glucose gelatin (deep punctures) show abundant gas formation which splits the media into many parts.

Gelatin is slowly liquefied by some strains, the digested material showing proteoses and peptones.

Broth is rapidly clouded and a heavy precipitate and growth collects in the bottom. The medium becomes acid to litmus and occasionally shows gas production. Dextrose broth gives marked gas.

On potato growth usually fails. Occasionally some growth and a small amount of gas production are noted.

I Wien. Klin. Wchnschr., 1905, 18, p. 921. 
Blood serum shows a greyish-white growth with a slight amount of digestion along the line of inoculation.

Milk, in 24 to 48 hours, shows casein, acid, and gas. The curd is riddled with gas bubbles, the so-called "stormy fermentation," and a distinct butyric acid odor is present.

Gas Production.-Gas production results in dextrose, lactose, and saccharose media, but according to my observations not in media containing mannite. This observation is at variance with that of some observers. Gas production sometimes occurs in media containing only the muscle sugar of the beef. Limited gas production also takes place in media containing only proteins, as originally pointed out by Welch. I was able to demonstrate this property in a one per cent solution of pure egg-white in a six-tenths per cent normal sodium chloride. The pure egg-white used was prepared after the method of Hopkins and three times recrystallized.

Gas production is much more rapid with $B$. welchii than with $B$. coli.

The gas produced is mainly carbon dioxide and hydrogen. According to Dunham the gas has the following composition:

$\begin{array}{lr}\text { Hydrogen } & 64.3 \% \\ \text { Carbon dioxide } & 27.8 \% \\ \text { Nitrogen, etc. } & 8.1 \%\end{array}$

Various other analyses have been made with slight variation.

Acid Production.-In cultures in dextrose broth the odor of butyric acid is quite marked and the cultures are markedly acid. Lactic acid is also shown to be present by Uffelman's reagent. Rodella ${ }^{2}$ states that all anaerobic bacteria develop organic acids. Expressed in terms of proprionic acid and calculating from the weight of barium salts, this writer found that $B$. welchii produced 0.257 grams acid for 100 per cent culture media (o. I04 acetic, O. 53 butyric).

Saccharo-butyric Fermentation and Putrefaction.-B. welchii is principally a zymogenic bacterium but possesses in addition saprogenic properties which are reduced or absent in some strains. Methylmercaptan and aromatic oxy-acids are usually produced.

As mentioned, the sugars are fermented with the possible exception of mannite; consequently gas and some organic acids, such as butyric, acetic, and lactic, are produced. Butyric acid is the principal fatty acid present and its odor is noticeable in fluid and cultures containing the organism. Rettger 3 substantiates Bienstock's 4 statement that obligate anaerobes are responsible for the putrefactive changes in the native proteins. He also found that while the bulk of the proteins is decreased the process never assumes the character of true putrefaction, and that gas can be produced in the absence of carbohydrates. Welch made this observation and so have $\mathrm{I}$. Fermentation and putrefaction of this kind go on in the proteins of the body with a post-mortem invasion of $B$. welchii. Fermentation is undoubtedly due to the presence of carbohydrate radicles in the proteins.

Thermal Death Point.-According to my observations, which are in agreement with those of other writers, the thermal death point for the vegetative forms of $B$. welchii

\footnotetext{
' Bull. Johns Hopkins Hesp., I897, 8, p. 68.

- Ann. de l'Inst. Pasteur, 1905, 19, p. 804; Centralbl. f. Bakt, 1003, 33, p. 135.

3 Jour, Biol. Chem., r9o8, 4 , p. 45.

4 Arch.f. Hyg., z899, 36, p. 335; ibid., rgor, 39, p. 390
} 
is $56^{\circ} \mathrm{C}$. for 10 minutes. The spore-bearing cultures were found to be killed at an average of $100^{\circ} \mathrm{C}$. for 15 minutes.

Pathogenic Power and Lesions Produced by $B$. welchii.-Among the lower animals infections by $B$. welchii are rare under natural conditions. Gaseous phlegmons have been observed by Harris ${ }^{x}$ in rabbits and dogs following injuries. It has been stated by many writers that rabbits and mice are practically immune to artificial inoculation and that guinea-pigs and pigeons are susceptible. I have noted in my experiments that some rabbits possess a certain degree of immunity even when large numbers of bacteria are injected directly into the circulation, but that guinea-pigs are readily susceptible. Rabbits, however, are not immune to the extent most writers infer. I have repeatedly observed rabbits to succumb to intravenous inoculation, no point of necrosis or disease being found post mortem, as claimed by some to be necessary for infection. ${ }^{2}$ Rabbits do not succumb to subcutaneous inoculation. As before mentioned, dead rabbits furnish an excellent medium for the growth of $B$. welchii, but this may be due to a loss of the bactericidal power of the blood.

The pathogenic properties of different strains of $B$. welchii vary for guinea-pigs when injected subcutaneously. Some strains are harmless, some produce death, and some subcutaneous hemorrhagic emphysema, edema, and necrosis.

One of the important questions often raised in connection with $B$. welchii concerns its invasion of the blood and tissues of the body. In a large percentage of general infections with this organism, the gas production and other changes are noted only after death. The tissues reveal a peculiar protein digestive process, are crepitant and emphysematous, filled with inflammable gas. The organs, especially the liver, may be riddled with gas cysts.

B. welchii has been observed in the blood one hour after death, but, as Welch states, this is sufficient time for the bacteria which have gained entrance into the tissues to multiply and produce gas. If we bear in mind the fact that $B$. welchii is a normal inhabitant of the intestinal tract of man and some animals, and may produce local lesions in this tract (Howard), it is easy to see how the tissues may be rapidly invaded from this source. It may be stated in this connection that in rabbits injected intravenously with milk-whey $(0.25$ c.c.) containing $B$. welchii and killed in three minutes and incubated at $37^{\circ} \mathrm{C}$. for one hour, I have observed in the liver a loss of nuclear staining power around the interlobular vessels and in some instances minute gas cysts. It seems probable that $B$. welchii never produces gas in the blood in the living body and consequently is not a factor in the production of gaseous emboli as has been supposed.

At all events there are no well-authenticated cases on record of a generalized digestion of tissues or intravascular gas production ante mortem. Welch mentions several cases in the older literature but these lack substantiation. If there is present anywhere in the body, but usually on the exposed surfaces, any necrotic tissue $B$. welchi $i$ may grow with rapidity and produce the characteristic saccharo-butyric fermentation with slight amounts of gas production. However, in these cases the tissue is for all practical purposes dead and separated from the rest of the body. It seems, therefore, that the body fluids under ordinary conditions are antibacterial or do not furnish the nutrient requirements which are supplied post mortem. This condition is rather

I Cited by Welch, Bull. Johns Hopkins Hosp., rgoo, I I, p. т85.

- Welch states that rabbits withstand large inoculations unless there exists necrotic or damaged tissue somewhere in the body which offers no resistance to infections. 
difficult to conceive, altho it has been shown, for example, that antibacterial properties of sera in snake venum poisoning entirely disappear post mortem. . Some observers claim to have isolated $B$. welchii from the blood during life; in such cases the antibacterial influences may have been sufficient to destroy the aerogenic and to attenuate the pathogenic properties of the organism. No gas production was observed in these cases and an etiological connection between the organisms and the pathological lesions could not be established.

Since Welch's" article in rgoo on the subject of "The Morbid Conditions Produced by Bacillus Aerogenes Capsulatus" the organism has been reported in many of the conditions noted by him. Among the more interesting may be mentioned those reported by Chosky, 3 Uffenheimer, 4 Holmsen, 5 Mooers, ${ }^{6}$ Blynie,7 Eagleton, 8 Puneo,9 Sappington, ${ }^{\circ}$ Dudgeon, 14 Cotton and Blake, ${ }^{2}$ Coley, 3 Whitacre, 4 Loving, ${ }^{5}$ and Schultz. 6

One of the most interesting and suggestive articles dealing with $B$. welchii is by Herter. 7

Herter raises the question as to the relation of primary pernicious anemia and some of the intestinal bacterial processes. Marked derangements of digestion and increase of $B$. welchi $i$ in the intestines are present in this disease and Herter suggests that the resulting saccharo-butyric putrefaction may give rise to toxic products that cause anemia. Herter finds that as the number of $B$. welchii increases in the intestine the number of $B$. coli diminishes and that there is also a simultaneous decrease in the erythrocytes. $B$. coli then would seem to hold $B$. welchii in check. Herter further holds that all gram-positive anaerobes in the intestine are $B$. welchii or sub-varieties.

\section{THE TOXIC SUBSTANCES PRODUCED BY B. WELCHII.}

In an investigation of immunity to $B$. welchii it is, of course, essential to have a clear understanding if possible of the nature of the toxic substances which this organism produces under various conditions.

In order to ascertain whether toxic substances are produced by B. welchii the organism was cultivated from garden earth on the various media under strict or partial anaerobic conditions. The following media were used: agar, gelatin, plain broth, broth with peptone I per cent, dextrose broth (I per cent peptone, I per cent dextrose), milk, and blood serum.

\footnotetext{
Ewing, Lancet, 1804,1, p. 1236 .

4 Beit, z. Path. Anal, 1902, 31, p. 383

2Bull. Johns Hopkins Hosp., 1900, I 1, p. 185. \& N. Mag. f. Laegev, 1903, No. 5.

3 Lancel, 1001, 2, p. 1572.

6 Bosion Med. and Surg. Jour., 1903, 143, p. 329.

${ }^{7}$ Limousen. Mêd., 1003, 27, p. 27.

8 Jour. Med. Soc. New Jersey, r904-1905, I, p. 97.

- Ibid., 1004-1905, I, p. 274.

to N. Y. Med. Jotur., 1904, 79, p. 641.

17 Trans. Path. Soc., London, r905, 56, p. 42.

1 Boston Med. and Surg. Jour., 1006, I55, p. 646.

'3 Mobile Med. and Surg. Jour., I907, 10, p. 304.

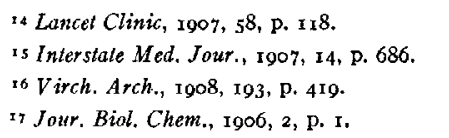


It was found that dextrose broth undoubtedly is the best medium, at least in giving the maximum acidity, and in my experiments dextrose broth was used unless otherwise stated.

Intravenous injection of $0.3-0.5$ c.c. of a 24 -hour broth culture of $B$. welchii in 8 to $\mathbf{I} 2$ hours in rabbits (which according to some writers are immune) gave rise to distinct evidences of intoxication in the majority of animals. In 25 per cent of the rabbits tested with the above amounts, death, preceded by a marked dyspnea, stupor, and later by convulsions in some cases, resulted in from 10 to I2 hours. In a few rabbits death did not result for 48 to 96 hours after injection. The animals dying in the period of intoxication usually have in the beginning a temperature of about $104: 5 \mathrm{~F}$., followed by a fall to about $96^{\circ} \mathrm{F}$. and death. Filtrates of cultures (Berkefeld, Pasteur-Chamberland) produced the same intoxication in rabbits but it required about $2-5$ c.c. intravenously, to cause death.

It may be stated here that I have observed a great variation in the resistance of various rabbits to $B$. welchii. Two animals of same weight, sex, and litter may react differently. Intraperitoneal injections of cultures and filtrates in rabbits of different ages were not fatal in 90 per cent. Subcutaneous injection of 0.5 c.c. produced no effects. However, when injected subcutaneously with larger doses of 24 -hour cultures $(2-5$ c.c.) gaseous phlegmons resulted in a few instances. With cultures three or four days old the toxic effects seemed to be more pronounced.

In guinea-pigs the toxic effects of cultures and filtrates were decidedly more pronounced than in rabbits, the intracardiac injection of 0.25 c.c. usually causing death in from six to eight hours. The corresponding amounts intraperitoneally usually produced similar results. Subcutaneous injection of cultures gave rise in a large percentage of cases to gaseous and gangrenous abscesses, and to death in a short period.

All experiments were carefully controlled by the injection of uninoculated culture media.

The Action of Heat on the Toxic Substances.-Of the heated filtrate of a 48 -hour dextrose broth culture 0.5 c.c. was injected intraperitoneally and intracardiacly in guinea-pigs of the same age and weight (Table I). An equivalent amount of dextrose broth alone gave no symptoms. 


\begin{tabular}{|c|c|c|c|}
\hline \multicolumn{4}{|c|}{ Toxictry of Heated Cultures. } \\
\hline $\begin{array}{c}\text { Temperature } \\
50^{\circ} \mathrm{C} \text {. } \\
50^{\circ} \\
60^{\circ}\end{array}$ & $\begin{array}{l}\text { Time } \\
20 \text { min. } \\
60 " ، \\
،\end{array}$ & $\begin{array}{c}\text { Result } \\
\text { Toxic } \\
\text { "، } \\
\text { "6 }\end{array}$ & \\
\hline $70^{\circ}$ & " $"$ & “ & Slightly reduced after $2 \mathrm{hrs}$. \\
\hline $90^{\circ}$ & 346 & “ & Reduced \\
\hline $100^{\circ}$ & " " " & " & Greatly reduced \\
\hline $100^{\circ}$ & $120 "$ & Slight & \\
\hline
\end{tabular}

This experiment, repeated with similar results, admits of but one interpretation. The toxic substance or substances in question do not seem to be true bacterial toxins because they are not completely destroyed by heating at $80^{\circ} \mathrm{C}$. or above for 60 minutes. It concerns a substance which resists $90^{\circ} \mathrm{C}$. $-100^{\circ} \mathrm{C}$., at which temperature it is rendered partially inactive. A temperature of $100^{\circ} \mathrm{C}$. for two hours destroyed the toxicity nearly completely.

On heating with a reflux condenser a definite amount of a 48 -hour culture and duplicating the foregoing experiment a slight reduction only in the amount of toxicity occurred after two hours, showing quite conclusively that the toxic substances had been volatilized to a large extent in the preceding experiments.

The Acids in the Cultures. - Now cultures in milk or in sugarbroth solutions in a short period reveal a distinct odor of butyric acid. It was therefore deemed advisable to test the cultures as to acidity (Table 2).

TABLE 2.

Determination of Acidity of Culfures in Dextrose Broth.

\begin{tabular}{|c|c|c|c|c|c|c|}
\hline Days & Titration A & Titration B & 'Titration C & Average & Media & Acjd \\
\hline 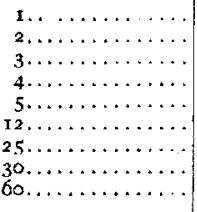 & $\begin{array}{l}.024 \% \\
.037 \\
.038 \\
.038 \\
.035 \\
.022 \\
.015 \\
.015 \\
.015\end{array}$ & $\begin{array}{l}.026 \% \\
.037 \\
.038 \\
.038 \\
.034 \\
.021 \\
.015 \\
.017 \\
.016\end{array}$ & $\begin{array}{l}.025 \% \\
.038 \\
.038 \\
.037 \\
.035 \\
.025 \\
.020 \\
.016 \\
.055\end{array}$ & $\begin{array}{l}.025 \% \\
.037 \\
.038 \\
.037 \\
.034 \\
.022 \\
.016 \\
.016 \\
.015\end{array}$ & $\begin{array}{l}.008 \% \\
4 \\
4 \\
4 \\
" 4 \\
4 \\
4 \\
" 6\end{array}$ & $\begin{array}{l}.017 \% \\
.024 \\
.030 \\
029 \\
.026 \\
.024 \\
.008 \\
.008 \\
.007\end{array}$ \\
\hline
\end{tabular}

Titrations made with $\mathrm{N} /$ a $\mathrm{NaOH}$, phenolpthalein indicator. Incubation $37^{\circ} \mathrm{C}$.

The titrations were made with three different cultures, A, B, C, in the same medium. A few cultures not included in this series showed no decrease in the amount of acid produced in 60 days $(0.025$ per cent was noted in one case). The normal for the culture medium remained 0.008 per cent in the whole series. From the foregoing table it is seen that the amount of acid present increases up to a 
certain point and then diminishes but at 60 days the acid has not been completely neutralized or decomposed. The decrease in the acidity may be owing to the formation of ammonia compounds, or the decomposition of the acid by the bacterial secretions. It is known that butyric acid organisms often produce substances which will decompose the butyric acid formed.

The next step taken was the determination of the acids in the cultures. A cursory examination by the usual qualitative methods showed butyric acid to be the principal acid present with acetic and lactic acid in smaller amounts. In all probability other organic acids also occur in smaller amounts. It is impossible to tell the exact percentage of acidity due to butyric acid.

The Toxic Action of Butyric Acid Compared with Toxic Action of Culture Filtrates.-The question as to what part of the toxic action of $B$. welchii is due to these organ ic acids naturally arises.

Normal butyric acid (Kahlbaum) was used in the following experiments in which guinea-pigs were injected. The exact nature of the toxic action of butyric acid is discussed subsequently.

TABLE 3.

The Toxic Action of Normal Butyric Acid Full Strength (ioo) on Intracardiac Injection in Guinea-Pig.

Amount of Acid
0.25 c.c.
0.15 "
0.1 "
0.05 "
0.025 "

Titrations made with $\mathrm{N} / \mathrm{r} \mathrm{NaOH}$, phenolphthalcin indicator.

Result
Death I min.; convulsions

" $2 \frac{1}{2}$ " "

" $2 \frac{1}{2}$ " "

" 15 " $"$

Severe symptoms-convulsions slight

Intraperitoneal injections of 0.25 c.c. of full-strength butyric acid caused marked peritoneal irritation followed by recovery and subcutaneous injection of the same amount caused a necrotic inflammation also followed by recovery.

TABLE 4 .

The Toxic Action of Butyric Acid i 500 on Intracardiac Injection in Guinea-Pig.

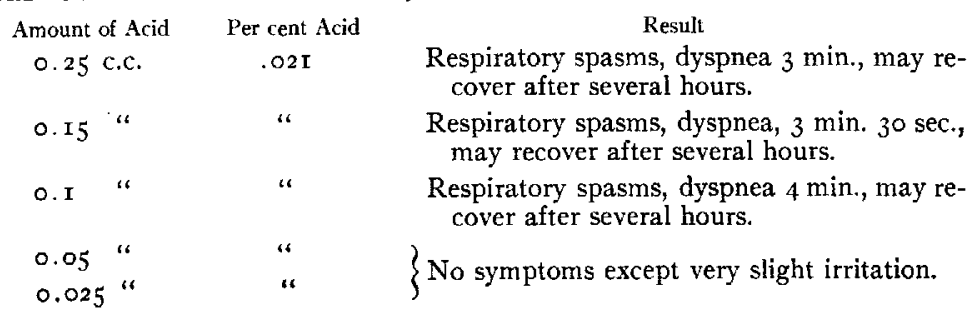


Intraperitoneal and subcutaneous injections of 0.25 c.c., I:500 butyric acid gave no effects.

Normal butyric acid $\mathrm{r}: 500$ shows an acidity of about 0.021 per cent, i. e., approximately about the same amount of acid as is produced in a 24 -hour culture of $B$. welchii in dextrose broth.

TABLE 5.

The Toxicity of Butyric Acio Fuid Strength on Intravenous Injection in Rabitss.

$\begin{array}{lc}\text { Amount of Acid } & \text { Per cent Acid } \\ 0.25 \text { c.c. } & \text { I } 2.3 \\ 0.15 \text { "6 } & \text { " } \\ 0.1 & \text { " } \\ 0.05 \text { " } & \text { " } \\ 0.025 " & 4\end{array}$

Death 3 hours. Convulsions.

" I2 " 2 " 5 " 4 "

Severe symptoms, often eventual death.

Symptoms less severe, occasional death.

TABLE 6.

The Toxic Action of Butyric Acid I 500 on Intravenous Injection in RabBits.

$\begin{array}{cc}\text { Amount of Acid } & \text { Per cent Acid } \\ 0.25 \text { c.C. } & 02 I \\ 0.15 \text { " } & \text { " } \\ 0.10 \text { " } & \text { " } \\ 0.05 \text { " } & \text { " }\end{array}$

Results

Severe symptoms, occasionally die. Respiratory paralysis, dyspnea.

Severe symptoms, usually recover.

Symptoms less severe, tremors.

Slight fever.

No symptoms.

Some-irritation on intraperitoneal and subcutaneous injection of 0.25 c.c.; no effect with injections of $\mathrm{I}: 500$.

A comparison of these two series of experiments shows the difference in the susceptibility of guinea-pigs and rabbits to normal butyric acid. The same condition occurs on injection of cultures and of filtrates of $B$. welchii. In rabbits $0.3-0.5$ c.c. of cultures $(24-48 \mathrm{hrs}$.) produce intoxication on intravenous injections (acidity $0.025-0.037$ per cent). and normal butyric acid $\mathrm{I}: 500$ intravenously in doses of $0.25^{-\mathrm{T}} .00$ c.c. (acidity $0.02 \mathrm{I}$ per cent) produces similar results.

Guinea-pigs and occasionally rabbits on subcutaneous injection of normal butyric acid full strength often develop deep phlegmons which break and suppurate. The tissue in the region of the acid becomes rapidly necrotic. In the beginning sterile pus is present, but later mixed infections occur.

After carefully neutralizing the filtrate of 48 -hour cultures of $B$. welchii with $0 . \mathrm{I}$ per cent sodium bicarbonate and also by 0.05 per cent sodium hydroxide and injecting in a series as given above, uniformly negative results were obtained. 
Inoculation with Washed Bacteria.-Twenty-four hour cultures grown in dextrose broth and centrifugated, washed three times in 0.85 per cent $\mathrm{NaCl}$ solution, were injected in doses of $0.25-0.5$ c.c. in 0.85 per cent $\mathrm{NaCl}$, intravenously and intraperitoneally in guineapigs and rabbits. In rabbits no symptoms resulted; a few guineapigs inoculated by intracardiac method showed signs of slight intoxication.

Autolytic Extracts of B. welchii.-Broth cultures were grown under paraffin oil, precipitated by centrifugalization, and subsequently washed three times with 0.85 per cent $\mathrm{NaCl}$ solution. The precipitate was then placed in a sterile mechanical ball mortar and ground for one and two hours until the bacteria were disintegrated. The material was now allowed to digest from four to six hours at $37^{\circ} \mathrm{C}$. and tested as follows:

A thick emulsion of the ground bacteria was made in 0.85 per

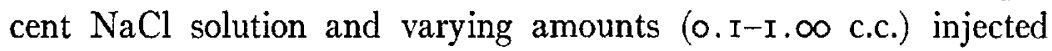
in rabbits and guinea-pigs both by intraperitoneal and intravenous methods. The rabbits showed no symptoms and several guineapigs showed only slight evidences of intoxication. No distinct toxin could be isolated by filtration. On digesting the material for several days and injecting guinea-pigs and rabbits during this period, no toxic substance could be demonstrated.

Previous Observations on the Toxic Substances.-Passinir describes some of his observations on the toxic substances produced by $B$. welchii (B. phlegmones emphysematosae Fraenkel). He states that this organism produces two distinct toxic substances: one which causes rapid death in animais by disturbances of respiratory and circulatory centers and another which causes vomiting, later diarrhea and death in from Io to $\mathrm{I} 2$ hours. These toxic substances are produced in 14 to 30 days at $37^{\circ} \mathrm{C}$. Passini states that 0.5 c.C. $-\mathrm{I} .5$ C.c. of Pukall-filtrate causes death in a rabbit weighing one kilo in 30 to 60 seconds when injected intravenously. These animals show two types of intoxication. Some have motor disturbances during which the animal races across the room colliding with many obstacles and later develops convulsions and dies. Others after to to 20 seconds become paralyzed in the head and limbs and later death occurs. Mechanical irritation is attended by some incoordinate response; non-fatal doses produce intoxication. Subcutaneous injection of 3 c.c. of a filtrate into $250-300$ gram guinea-pigs is followed by similar symptoms. Passini notes a variation in the centers attacked by toxins derived from different strains. For example, one culture derived from the feces of a patient with pernicious anemia produced a toxic substance which acted primarily upon the respiratory center and another procured from Kral's laboratory acted primarily on the circulatory and nervous systems.

เWien. klin. Wchnschr., 1905, x8, p. 921. 
This irregularity suggests different organisms. Furthermore, Passini's medium was prepared by digesting beef muscle with trypsin. He does not consider the possibility of the proteoses and peptones, etc., produced in this process being toxic in themselves. Neither does he consider the acid produced a factor. He states, however, that if one per cent dextrose is used that the "acid end product" is toxic. The same writer states that some media on standing three or four weeks at $37^{\circ} \mathrm{C}$. become distinctly alkaline and that on subcutaneous infection of 3 c.c., hemorrhagic edema is produced. $\mathrm{He}$ also notes that $60^{\circ} \mathrm{C}$. for one hour or $100^{\circ} \mathrm{C}$. for 15 minutes does not impair the toxic action of the filtrate to any great degree. He isolated no distinct toxin and does not elucidate any of the problems of immunity.

Kamen found that filtrates of cultures from a surgical phlegmon were faintly hemolytic and leukolytic for the blood cells of man, dogs, guinea-pigs, and rabbits. He could isolate no distinct toxin or lytic agent.

Herter $^{2}$ states that $B$. welchii produces a moderately toxic (hemolytic) substance. Heating at $70^{\circ} \mathrm{C}$. for one hour with exhaustion reduced the toxic substance in its activity and $100^{\circ} \mathrm{C}$. does not destroy it according to this author. No distinct toxin could be isolated even after careful neutralization of the acid. Herter's work will be referred to again in the discussion of the specific action of the toxic substances.

E. Fraenkel 3 and Hitchman and Lindenthal 4 among others failed to isolate any toxin from B. welchii.

\section{HEMOLYSINS PRODUCED BY B. WEICHII,}

It has been stated by some investigators that $B$. welchii produces hemolytic substances. The nature of these substances has never

TABLE 7 .

The Action of Filtrate of 24 -Hour Culture $(0.025 \%$ ACrD) on Normal Rabbit Corpuscles.

\begin{tabular}{|c|c|c|c|}
\hline \multirow{2}{*}{ Amonnt of Filtrate } & \multicolumn{3}{|c|}{ HEMOLYSIS } \\
\hline & Filtrate I & Filtrate 2 & Filtrate 3 \\
\hline 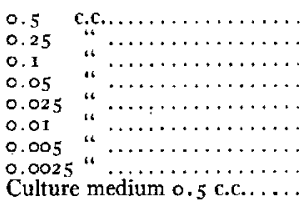 & $\begin{array}{l}\text { complete } \\
\text { al. complete } \\
\text { marked } \\
\text { medium } \\
0 \\
0 \\
0 \\
0 \\
0\end{array}$ & $\begin{array}{l}\text { complete } \\
\text { al. complete } \\
\text { marked } \\
\text { medium } \\
\text { slight } \\
\text { trice } \\
\qquad \\
0 \\
0\end{array}$ & $\begin{array}{l}\text { complete } \\
\text { complete } \\
\text { al. complete } \\
\text { marked } \\
\text { slight } \\
\text { trace } \\
\text { trace (?) } \\
\quad 0 \\
\quad 0\end{array}$ \\
\hline
\end{tabular}

Filtrates Nos. I, 2 , and 3 were from three strains of $B$. welchii.

been satisfactorily explained. The following experiments were made in the hope of gaining accurate information on these so-called hemolysins.

The erythrocytes used were in 5 per cent suspension and washed

× Ceniralbl. f. Bakt., т904, 35, p. 686.

Jour. Biol. Chem., I9o6, 2, p. I.

3 Ergebnisse der Path., I902, 8, p. 403 .

4 Sitzung d. k. Akad. d. Wiss. Wien, 1901, 110, Sep. 
three times with 20 volumes of 0.85 per cent $\mathrm{NaCl}$ solution. The hemolytic mixtures were incubated for one hour at $37^{\circ} \mathrm{C}$., shaken, and again incubated one hour, when the tubes were shaken again and placed in the ice chest for $\mathbf{2} 2$ hours. Hemolysis usually occurred in from 30 to 60 minutes. Each tube contained I c.c. of a 5 per cent suspension of rabbit corpuscles, the indicated amount of filtrate, and enough $\mathrm{NaCl}$ solution to make the total quantity 2 c.c.

Similar experiments with whole cultures gave the same results and the corpuscles of injected rabbits were affected in the same way as normal corpuscles. Tubes containing filtrate $(0.25-0.5$ c.c.) often show a marked precipitate of proteins.

It is important to note that in these experiments really typical hemolysis did not occur altho all the erythrocytes were disintegrated. In tubes indicated as "complete, almost complete," etc., the color was not the typical reddish-cherry color but a reddish- or yellowish-brown and in some cases a brownish-violet color. Tubes of this kind showed on spectroscopic analysis, methemoglobin. I have determined that this appearance is probably due to the organic acids produced by the bacteria in the culture before filtration. Mixtures in the hemolyzed tubes are distinctly acid to litmus. The same color is noted when pure butyric acid (Kahlbaum) is mixed with 0.5 per cent rabbit or guinea-pig erythrocytes.

Having observed that guinea-pigs are much more susceptible to infections with $B$. welchii than rabbits, I next tested in the same way the effect of $24^{-}$and 72 -hour cultures on the erythrocytes of the guinea-pig.

TABLE 8.

The Action of Filtrate of 24 -Hour Cultures on Normal Guinea-Pig Corpuscles.

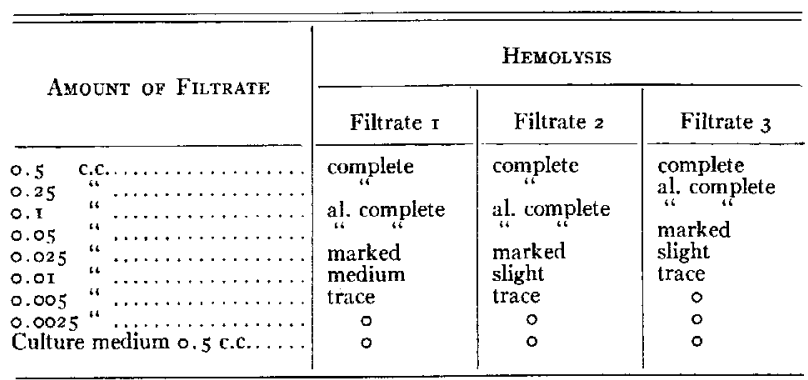

Cultures and filtrates (48-72 hours old, $0.037-0.038$ per cent acid) gave practically the same results. Methemoglobin was produced as in case of rabbit corpuscles. 
Cultures and filtrates were tested on 5 per cent suspensions of the erythrocytes of the pigeon, sheep, goat, and monkey also, and a typical hemolysis was produced in each case. In the case of the goat blood there was a marked protein precipitate in the tubes containing the largest amount of culture or filtrate. Its nature was not investigated.

The Action of Normal Butyric Acid I : 500 (0.02I per cent) on Normal Rabbit Corpuscles.--Since it has been shown that the butyric and closely allied acids which are produced by $B$. welchii in culture under certain conditions are toxic for rabbits and guinea-pigs, the action of this acid upon the erythrocytes of these species was studied.

TABLE 9 .

The Lytic Action of Butyric Acid i : 500 on RabBit Corpuscles.

Amount of Acd
1.00 c.c.
0.5
0.25 " "
0.15 "
0.1
0.05 "

Lysis

complete

al. complete.

" "

slight

o

Each tube contained $x$ c.c. 5 per cent suspension of corpuscles, the amount of acid $x: 500$ indicated, and enough $\mathrm{NaCl}$ solution to make 2 c.c. The yellowish-brown methemoglobin color was prominent, since pure acid was used.

Neutralization of Filtrates of Cultures.--The filtrates of cultures and the cultures themselves being hemolytic and methemoglobin being produced by butyric and allied organic acids, the next step was carefully to neutralize the acid in the cultures and then test their lytic action on various erythrocytes.

For this purpose 0 . I per cent sodium bicarbonate in 0.85 per cent $\mathrm{NaCl}$ (non-hemolytic for guinea-pig and rabbit corpuscles) was used with phenolphthalein as an indicator. A solution of 0.05 per cent $\mathrm{NaOH}$ was also used for the purpose of neutralization, but it was not satisfactory as the hydroxyl ions $(\mathrm{OH})$ are so strongly hemolytic that even with the most careful technic in neutralization enough excess of $\mathrm{NaOH}$ may result to cause lysis.

The neutralized filtrates of $24^{-72}$ hour cultures were found to have no lytic action on rabbit and guinea-pig erythrocytes in several series of tests. Sometimes, however, tubes containing 0.5 c.c. and 0.25 c.c. filtrate seemed to show the presence of an agent producing slight 
typical hemolysis. On heating the neutralized filtrates for $30 \mathrm{~min}-$ utes at $80^{\circ} \mathrm{C}$. the lytic agent entirely disappeared. The possibility of the presence of a typical bacterial hemolysin naturally suggested itself, but since the thermolabile hemolytic agent was found in two series only the lysis may have been due to some unknown fault in technic, such as an excess of the neutralizing agent and liberation of carbon dioxide.

Jordan ${ }^{\mathrm{I}}$ has shown that a hemolytic thermostable precipitate is produced in broth as it becomes alkalin. There is a possibility that such substances may be produced in this case although none have been demonstrated.

Herter $^{2}$ states that $B$. welchii produces moderately active hemolytic substance or substances. He carefully neutralized 0.5 c.c. of filtrate and found that it induced hemolysis in rabbit and monkey (Rhesus) erythrocytes. He treated the filtrate by exhaustion and it reduced the hemolytic action slightly. Heating to $70^{\circ} \mathrm{C}$. for an hour reduced it still further. He also states that boiling does not destroy the hemolytic agent. In order to ascertain whether hemolysis was due to volatile ammonia compounds, Herter rendered the filtrates of the cultures alkalin with $\mathrm{NaHCO}_{3}$, concentrated it at reduced pressure to drive off ammonia, then restored the volume with 0.85 per cent $\mathrm{NaCl}$. He states that this procedure reduced the hemolytic action of the filtrate somewhat. Herter does not seem to regard the acids present as factors or to appreciate the fact that the $\mathrm{NaHCO}_{3}$ used in neutralization is a distinctly hemolytic substance in solutions over O. I-O. 5 per cent. Herter's report does not give details as to method.

Kamen ${ }^{3}$ found the filtrates of cultures hemolytic for the erythrocytes of man, dog, guinea-pigs, and rabbits. He does not refer to the acids produced and states that he could not isolate any definite toxic substance. The same is true of Passini, ${ }^{4}$ altho he seems to think that the toxin is not similar to an ordinary bacterial toxin but more closely allied to the products of certain putrefactive yeasts such as described by Faust. ${ }^{5}$

\footnotetext{
I Jour. Infect. Dis., 1905, 2, p. 51 I.

-Jour. Biol. Chem., 1906, 2, p. I.

3 Centralbl. f. Bakt., т904, 35, p. 686.

4 Wien. klin. Wchnschr., I905, I8, p. 921.

5 Cited by Passini, Wien. klin. Wchnschr, x905, 18, p. 921 .
} 
The Presence of Hemolysins in Rabbits Immunized with $B$. welchii.-Rabbits were immunized with injections of 48 -hour beef broth cultures, beginning with 0 . I c.c. and increasing the amounts to $1 . \infty$ c.c. The weight and temperature of the animals were used as guides to reinjection, which was made only when temperature and weight were normal.

The serum of rabbits two and three days after inoculation with o. I c.c. of 48 -hour culture causes no lysis of normal rabbit corpuscles nor of washed corpuscles of the injected rabbits.

Ten days after the first inoculation of 0 . I c.c. and two days after the second injection of 0.015 c.c. of 48 -hour culture, the sera of two rabbits in two series gave approximately the result in the one series given in Table ro.

TABLE 10.

The Presence of Lysin in Injected Rabbit Serum for Normag, Rabbit Corpuscles.

$\begin{array}{lll}\text { Amount of Serum } & \text { Hemolysis } \\ 0.5 \text { c.c. } & \text { Slight } \\ 0.25 & \text { Trace } \\ 0.1 & \text { " } & \text { Faint trace } \\ 0.05 & \text { " } & 0 \\ 0.025 \text { " } & 0 \\ 0.1 & \text { " } & 0 \\ 0.005 \text { " } & 0 \\ 0.0025 " & 0 \\ 0.0 & \text { " } & \end{array}$

Each tube contained i c.c. of 5 per cent suspension of rabbit corpuscles, the amount of serum indicated, and enough $\mathrm{NaCl}$ solution to make 2 c.c. There was a slight brownish-yellow color of the fuid in the tube showing lysis.

A hemolytic agent having been demonstrated in this serum, it remained to determine its nature.

Twenty-four days after the first injection (o. I c.c.), I 2 days after the second injection ( 0.5 c.c.), and four days after the third injection ( $\mathrm{I} . \infty \mathrm{c}$ c.c.) of a 48 -hour culture of $B$. welchii the serum of the same rabbit gave the results shown in Table II.

TABIE II.

The Presence of Lysin in Injected Rabbit Serum for Normal Rabit Corpuscles.

\begin{tabular}{ll}
\multicolumn{2}{c}{ Serum } \\
0.5 c.c \\
0.25 " \\
0.1 " \\
0.05 " \\
0.025 " \\
0.01 " \\
0.005 " \\
0.0025 " \\
0.0
\end{tabular}
Hemolysis

Marked

Medium

Slight

Trace

Faint trace

o

$\circ$

o

$0.0 \quad 4$ 
Heating the serum from this rabbit at $56^{\circ} \mathrm{C}$. for one hour did not destroy the hemolytic agent. Heating to $70^{\circ} \mathrm{C}$. for three hours completely inactivated the serum but it could not be reactivated by means of normal guinea-pig or rabbit serum as complement.

The tubes exhibiting hemolysis in all these experiments often showed a brownish-yellow coloration like that when the filtrates of cultures were mixed with normal rabbit corpuscles.

In order to investigate further the question of a thermostable complement, I treated the sera according to the method of Ehrlich and Morgenroth: The serum was mixed with $\frac{1}{10}^{\frac{1}{0}}$ part of $\mathrm{N} / \mathrm{I}$ hydrochloric acid and digested at $37^{\circ} \mathrm{C}$. for 45 minutes. It was then carefully neutralized with 0.1 per cent sodium bicarbonate. A series with the same rabbit serum as used in Tables Io, II showed no hemolysis in any of the tubes. The serum could not be reactivated by normal rabbit and guinea-pig serum as complement. The experiment practically eliminates the possibility of a thermostable complement and the hemolysis must be ascribed to some chemical agent, possibly the salt of an acid produced by the bacteria. A logical explanation for the negative results in the above-mentioned experiment is found in the fact that hydrochloric acid frequently decomposes organic acids, and even providing this did not occur all the acid salts would be neutralized by the sodium bicarbonate.

As is well known, normal rabbit serum is usually slightly hemolytic for guinea-pig erythrocytes. The serum from a rabbit which on being tested had shown the peculiar brownish-yellow hemolysin was heated at $56^{\circ} \mathrm{C}$. for 30 minutes, thus destroying the normal complement. However, this serum still remained hemolytic for guinea-pig erythrocytes, showing the atypical nature of the hemolytic agent.

Since it has been shown that the cultures produce acid sufficient to cause lysis of rabbit corpuscles (atypical) and since there is a possibility of the acid in the culture not being rapidly excreted subsequent to injection but combining with some inorganic base in the serum and thus accounting for the hemolytic substances in the sera of immunized rabbits, I made some experiments with butyric acid.

It was found that in rabbits which recovered from injections of I:500 normal butyric acid there was present two days after inoculation in the sera an agent which would produce the peculiar brownish- 
yellow lysis of normal rabbit erythrocytes. This action was confined to the erythrocytes of other rabbits and I was unable to detect any intravascular hemolysis in the injected rabbit. This substance which was undoubtedly a salt of the acid in the culture injected was not present after three days.

It was noted that in the rabbits which had received several doses of cultures the hemolytic agent was present for a somewhat longer time. In regard to the presence of leukocytotoxic substances in the serum of rabbits injected with broth cultures of $B$. zeelchii see p. 557 .

Leukocytolysis. - In connection with certain experiments on the phagocytosis of $B$. welchii, it was observed that the bacillus exerted a marked leukotoxic effect.

When the filtrates of 24 - and 48 -hour cultures of $B$. welchii and the washed leukocytes of the rabbit were brought together in capillary pipettes for periods varying from 2 to $x 5$ minutes at $37^{\circ} \mathrm{C}$., it was noted that lysis of the cytoplasm of the leukocytes was complete, together with marked vacuolization and loss of staining of the nuclei depending upon the time of contact. Broth alone had no effect on the cytoplasm of the leukocytes but produced a very slight vacuolization of the nuclei in some cases. Leukocytotoxic substances have also been described by Kamen ${ }^{\mathrm{I}}$ but were not isolated. When 24and 48-hour cultures were used instead of the filtrates the same changes were noted in the leukocytes and there was no phagocytosis.

Equal parts of serum, washed leukocytes, and bacterial filtrate were mixed in the dilated portion of a small glass pipette, the pipettes sealed and incubated at $37^{\circ} \mathrm{C}$. for varying periods. During the period of incubation the pipettes were occasionally rotated. Smears were stained with carbol-thionin. The leukocytes were obtained either from aleuronat pleural exudates or from blood cream, and were thoroughly washed with 0.85 per cent $\mathrm{NaCl}$ solution. It was noted that proportionately there were more polymorphonuclear leukocytes affected by the lytic substances than mononuclear leukocytes. The nuclei showed the most pronounced affects, there being vacuolization even after three minutes' incubation.

The vacuolization of the nuclei of the leukocytes in leukocytotoxin tests, etc, has also been noted by Eisenberg ${ }^{2}$ in the case of two other

- Centralbl. f. Bakt., I904, 35, p. 686 .

- Compl. rend. Soc. de Biol. 1007, 62, p. 49J; Ann. de l'Inst. Pasteur, 1908, 22, p. 430. 
anaerobes, namely, $B$. edematis maligni and $B$. anthracis symptomatique, and by Gheroghiewsky ${ }^{1}$ in Ps. pyocyanea. Eisenberg claims to have demonstrated an antileukocidin in symptomatic anthrax. Eisenberg regards his leukotoxin as a thermolabile substance and he states that chemotaxis is negative to all pathogenic anaerobes.

\section{THE ANTIOPSONIC ACTION OF FILTRATES OF CULTURES OF B. WELCHII.}

Hektoen $^{2}$ has shown that lactic acid acts as an antiopsonic substance preventing opsonins from sensitizing bacteria. He demonstrated that in the dilutions used, lactic acid does not affect the leukocytes or bacteria. Cultures of $B$. welchii contain butyric acid and some lactic acid, and consequently I undertook to investigate the effect of these substances. It was noted that when 24-hour broth cultures were used there was extensive leukocytolysis and no phagocytosis, while with washed bacteria there was phagocytosis. In order to study the action of the acid substances on the opsonins, the following experiment was made, modifying slightly the experiments made by Hektoen on lactic acid.

I. 0.2 c.c. serum to. 05 c.c. filtrate $(+0.03)$ incubated at $37^{\circ} \mathrm{C}$. one hour, then added washed bacteria 0.5 c.c. + washed rabbit leukocytes and incubated at $37^{\circ} \mathrm{C}$. for 30 minutes. No phagocytosis, leukocytolysis marked.

2. 0.2 c.c. serum to. 05 c.c. $(+0.03)$ filtrate + washed bacteria 0.5 c.c., incubated at $37^{\circ} \mathrm{C}$. one hour; rewashed bacteria, then added washed rabbit leukocytes and incubated at $37^{\circ} \mathrm{C}$. for 30 minutes. No phagocytosis.

Controls $(a)$ o. 2 c.c. serum +0.5 c.c. washed bacteria + washed rabbit leukocytes incubated at $37^{\circ} \mathrm{C}$. one hour. Phagocytosis. Some vacuolization.

(b) 0.2 c.c. serum +0.05 c.c. culture medium $(+.008)$ incubated at $37^{\circ} \mathrm{C}$. one hour, then added washed bacteria 0.5 c.c. + washed rabbit leukocytes, and incubated at $37^{\circ} \mathrm{C}$. 30 minutes. Phagocytosis slight.

(c) 0.2 c.c. serum +0.05 c.c. $\mathrm{NaCl}+$ washed bacteria $(0.5$ c.c. $)+$ washed leukocytes, incubated at $37^{\circ} \mathrm{C}$. one hour. Phagocytosis slight.

3. 0.2 c.c. serum +0.05 c.c. ( $+0.02 \mathrm{I}$ ) normal butyric acid, incubated at $37^{\circ} \mathrm{C}$. for one hour, then added washed bacteria 0.5 c.c. + washed leukocytes, and incubated at $37^{\circ} \mathrm{C}$. No phagocytosis. Leukocytolysis marked.

Controls (a) Washed bacteria (0.5 c.c.) + 0.02 c.c. ( $+0.02 \mathrm{I}$ ) normal butyric acid and incubated at $37^{\circ} \mathrm{C}$. for $3 \circ$ minutes. Rewashed bacteria + serum 0.2 c.c. incubated at $37^{\circ} \mathrm{C}$. one hour + washed leukocytes and incubated at $37^{\circ} \mathrm{C}$. 30 minutes. Phagocytosis.

'Ann. de l'Inst. Pasteur, 1896, 10, p. 580.

- Jour. Amer. Med. Assoc., ıgo6, 46, p. I411. 
The above experiments show, (r) that the acids in the culture filtrates are capable of inactivating the opsonins and that the cul-. ture media or sodium chloride alone has no effect. (2) That normal butyric acid (.02 I per cent) is antiopsonic. (3) That normal butyric acid and filtrates of cultures have very little or no effect upon the bacteria and their subsequent sensitization by opsonins in 30 minutes and that these substances are distinctly lytic for the leukocytes.

Hektoen is inclined to believe that antiopsonic action is really responsible for the seeming negative chemotaxis toward bacteria and my observations seem to corroborate this and in addition demonstrate that the acids produced in culture are also lytic for leukocytes and consequently chemotaxis may be markedly influenced for this reason also.

Guinea-pig leukocytes show no difference from rabbit leukocytes as far as leukocytolysis is concerned, altho these animals are much more susceptible to infection by $B$. welchii. Phagocytosis, however, is more active with rabbit leukocytes than with guinea-pig leukocytes.

THE ANTIGENIC PROPERTIES OF B. WELCHII.

The Opsonins for B. welchii in Normal and Immune Rabbit Sera.-When normal serum, washed leukocytes, and washed bacteria are brought together in capillary pipettes at $37^{\circ} \mathrm{C}$. for to to 15 minutes, a few of the leukocytes show a slight amount of lysis with vacuolization of the nuclei. An average phagocytosis of three or four bacteria may occur. On incubation for three to five minutes, two to four bacteria are taken up with only slight vacuolization of the nuclei and no lysis. No bacteria were taken up when serum was absent but when bacteria and leukocytes alone were in contact at $37^{\circ} \mathrm{C}$. for 15 minutes a slight amount of lysis occurred. The results obtained with guinea-pig leukocytes were somewhat lower. It would seem that three or four bacteria were the maximum number which the leukocytes are able to take up.

It was found that the washed bacteria should be derived from cultures not over 24 hours old as the acid produced gives rise to marked precipitation of the proteins of the media and this interferes materially with securing a good emulsion of the washed bacteria. 
Washed bacteria from the whey of milk cultures have been used with some success. Quite frequently, however, vacuolization of the nuclei occurs.

The rabbit used in one experiment (Table 12 ) had received three injections extending over a period of 20 days of 0 . I c.c., 0.5 c.c., and 0.5 c.c. of a 48 -hour culture, the last one on the day before the serum was drawn.

TABLE I2,

Ifeukocytotoxic Action of Serum of Immunjzed Rabait.

\begin{tabular}{|c|c|c|}
\hline Incubation & Leukolysis & Phagocytosis \\
\hline $\mathrm{x}_{5} \mathrm{~min}$. & Marked & 0 \\
\hline IO 6 & “ & 0.2 \\
\hline 5 “ & Vacuolization & 0.5 \\
\hline 3 & “ & 0.8 \\
\hline $3 "$ & slight & 0.7 \\
\hline I5 "No serum, NaCl Sol. & 0 & \\
\hline
\end{tabular}

Table 12 demonstrates that there was some substance in the serum of the immunized rabbit in addition to that contained in the bacteria, which was leukocytotoxic, and consequently phagocytosis was not active, only a few leukocytes containing bacteria. The bacteria used were from the same strain used in previous experiments and were grown in exactly the same culture media. Since we know that the salts of butyric acid are not readily eliminated from the body of the rabbit, and as the rabbit had received the last injection only one day previous to the experiment, the leukocytolysis is accounted for easily. Heated serum $\left(60^{\circ} \mathrm{C} .3^{\circ} \mathrm{min}\right.$.) caused vacuolization of the nuclei but no phagocytosis.

TABLE I3.

Opsonin for B. Welchil in SERUM OF IMMUNized RabBit

$\begin{array}{rcc}\text { Incubation } & \text { Leukolysis } & \text { Phagocytosis } \\ \text { I5 min. } & \text { Slight vac. } & 0.7 \\ \text { I0 " } & \text { " " } & 7 \cdot 5 \\ \text { 10 " } & \text { " " } & 7 \cdot 7 \\ 7 \text { " " } & \text { " } & 6 . \\ 5 \text { " } & \text { " } & 6 . \\ 3 \text { " No serum, } \mathrm{NaClSol} \text {. } & 0 & 5 . \\ \text { I5 "No } & 0.5 \\ \text { I5 "No serum, } \mathrm{NaClSol} \text {. } & 0 & 0.0\end{array}$

The rabbit used in this experiment (Table 13) had received 
three injections, extending over a period of 25 days, of o. I c.c., ०. 5 c.c., and 0.5 c.c. of a 48 -hour culture, the last Io days previously.

The table shows rapid phagocytosis especially in those tubes incubated seven minutes and less. Evidently there was little or no leukocytolytic acid substance in this serum.

After heating the immune serum to $60^{\circ} \mathrm{C}$. for $3 \circ \mathrm{min}$. it gave but little phagocytosis.

The Bactericidal Action of Immune Serum.-For the study of lysis of $B$. welchii by rabbit and guinea-pig serum the method of Neisser and Wechsberg was followed:

Each tube contained 0.0002 c.c. of a 24 -hour broth culture of the bacillus, 0.15 c.c. plain broth, the amount of serum indicated, and enough $\mathrm{NaCl}$ solution to make the total volume in each case 2.5 c.c. The tubes were incubated at $37^{\circ} \mathrm{C}$. for three hours when agar plates were made, using 0.25 c.c. of the mixture for each plate. The plates were incubated for 24 hours under anaerobic conditions ( $H$ gas) at $37^{\circ} \mathrm{C}$., when the number of colonies on each plate was estimated.

TABLE 14.

The Effect of Normal Rabbit Serum on B. Weir hil.

\begin{tabular}{|c|c|c|}
\hline \multicolumn{2}{|c|}{ Amount of Serum } & \multirow{2}{*}{$\underset{\infty}{\text { Number of Colonies }}$} \\
\hline 0.5 & c.c. & \\
\hline 0.25 & " & $\infty$ \\
\hline 0.1 & " & Thousands \\
\hline 0.05 & $"$ " & Hundreds \\
\hline 0.025 & “ & Hundreds \\
\hline 0.01 & $“$ & Hundreds (Isolated) \\
\hline 0.005 & “ & $\infty$ \\
\hline 0.0025 & $5 “$ & $\infty$ \\
\hline 0.05 & $"\left(\text { Heated to } 5^{6^{\circ}} \mathrm{C} .30 \mathrm{~min} .\right)^{*}$ & $\infty$ \\
\hline 0.05 & " " $"$ " & Hundreds \\
\hline 0.05 & " (No culture) & o \\
\hline 0.0 & (Culture) & $\infty$ \\
\hline
\end{tabular}

*=Guinea-pig serum complement (0.3 c.c.)

Table I4 shows that normal rabbit serum is slightly bactericidal; and this action is most marked in mixtures containing 0.025 c.c. and 0.01 c.c. of serum. Under similar conditions $0.025-0.01$ c.c. of normal guinea-pig serum is perhaps slightly bactericidal.

Table 15 gives the results obtained with the serum of rabbits immunized with $B$. welchii, heated to $56^{\circ} \mathrm{C}$. for 30 minutes and complemented with normal guinea-pig serum. The rabbit serum 
was obtained from animals that had received three injections of living cultures ( $0.1,0.5,0.5$ c.c.) extending over a period of 20 days.

TABLE 15.

The Effect of Immune Rabit Sfrum on B. Welchil.

\begin{tabular}{|c|c|c|}
\hline $\begin{array}{c}\text { Amount of Heated } \\
\text { Rabbit Serum }\end{array}$ & $\begin{array}{l}\text { Amount of Guinea- } \\
\text { Pig Serum }\end{array}$ & Number of Colonies \\
\hline 0.5 & 0.3 & $\infty$ \\
\hline 0.25 & "G & $\infty$ \\
\hline 0.1 & " & $\infty$ \\
\hline 0.05 & " & Thousands \\
\hline 0.025 & "t & Thousands \\
\hline 0.01 & " & Hundreds \\
\hline 0.005 & " & $5 I$ \\
\hline 0.0025 & “ & 78 \\
\hline 0.25 & .0 & $\infty$ \\
\hline$\circ$ & 0.3 & $\infty$ \\
\hline
\end{tabular}
Amount of Guinea-

The antibacterial action begins to show itself in the mixtures containing 0.05 c.c. of rabbit serum and is most marked in those containing 0.005 c.c. and 0.0025 c.c. On comparison of Table I4 with Table ${ }_{5}$ it is seen that the immune serum shows a slight increase in antibacterial power. The normal guinea-pig serum $(0.3$ c.c.) used as the complement is by itself without bactericidal action.

The maximum bactericidal action being caused by 0.01 to 0.005 c.c. of heated immune serum (amboceptor), it seemed advisable to use varying amounts of complement and a definite amount amboceptor to determine if 0.3 c.c. complement was the most efficient amount.

In the following series the amboceptor, culture, $\mathrm{NaCl}$ solution, and broth were mixed and placed at $37^{\circ} \mathrm{C}$. for one hour when complement was added and the mixture incubated for two additional hours.

TABLE I6.

The Effect of Immune Rabit Serum and Varying Amounts of Guinea-Pig Serum on B. welchit. Amount of Heated Amount of
Rabbit Serum Guinea-Pig Serum $0.005 \quad 0.005 \quad \infty$

" $0.01 \quad \infty$

" $0.05 \infty$

" $0.1 \quad \infty$ (slight reduction in no.)

" $0.2 \quad 70$

" $0.3 \quad 65$

" 0.4 Hundreds

" $.0 \quad \infty$

$\propto=$ Innumerable.

$$
\begin{aligned}
& \text { Number of Coloni es } \\
& \infty \\
& \infty \\
& \infty \text { (slight reduction in } \\
& 70 \\
& 65 \\
& \text { Hundreds } \\
& \infty \\
& \infty
\end{aligned}
$$$$
\infty
$$$$
\infty
$$ 
Here again the maximum antibacterial action was obtained in mixtures of $0.005-0.0025$ c.c. immune serum and $0.2-0.3$ c.c. guinea-pig serum. The interesting phenomenon of complement deviation is well illustrated in Tables 15 and 16 .

Evidently normal and immune rabbit serum at proper concentration is distinctly bactericidal for B. welchii. Microscopic examination shows the bacteria in the mixtures intact but dead, so that no growth could be obtained with them. No effect was obtained on animal inoculation. There was no evidence of any disintegration among the bacterial cells. The process is therefore evidently a bactericidal and not a bacteriolytic one.

Agglutinins.-According to Scheffler, ${ }^{1}$ Clairmont and Rothbergers, ${ }^{2}$ specific agglutinins are produced on immunization with $B$. welchii. Clairmont found the sera of animals immunized with one strain of $B$. welchii to agglutinate not only the homologous strain but also all strains coming from infant stools. Passini ${ }^{3}$ found the agglutinins produced in some related antisera and in the homologous sera when different strains were used. Werner ${ }^{4}$ secured an agglutinating serum which acted in dilutions of $\mathrm{r}: 1000$.

Some observers, among them Kamen, ${ }^{5}$ have been unable to demonstrate agglutinins in the sera of immunized animals.

The bacteria in my experiments were obtained from a 24 -hour culture grown in Io c.c. of broth under paraffin oil. The mixtures of bacteria and serum dilutions were incubated at $37^{\circ} \mathrm{C}$. for varying periods. The presence or absence of agglutination was determined by naked eye at times assisted by microscopic examination.

The agglutinins begin to appear in the serum about the sixth or seventh day after injection of the heated $\left(60^{\circ} \mathrm{C} .30 \mathrm{~min}\right.$.) bacterial culture and increase until the I2th or 14 th day. On reinoculation several times the agglutinins may be increased markedly. In the case of the serum of a rabbit receiving four injections of live bacteria (O. I, $0.3,0.5,0.5$ c.c.) in the course of 24 days distinct agglutination was obtained in dilutions of $I: I 200$ after an incubation of three

: Cited by Paltauf, Kolle w. Wassermann Handbuch, I g04, 4, p. 706.

- Ibid.

3 Wien. klin. Wchnschr., 1005, 18, p: 921.

4 Arch. F. Hyg., 1904, 50, p. 274 ; 1905, 53, p. 128.

sCentralbl. f. Bakl, igo4, 35, PD, 554-686. 
hours. The maximum and most typical agglutination occurred at $I: 500$ dilution in $2 \frac{1}{2}$ hours. Not all rabbits produce agglutinins to the same extent and a serum agglutinating $I: 1000$ is rare.

Precipitins.-During the immunization of rabbits with $B$. welchii precipitins develop in the serum, as well as opsonins, bactericidal substances, and agglutinins. The precipitins appear about the seventh day and gradually increase until about the 12 th- 14 th day when a gradual decline begins.

In order to demonstrate precipitins 24 - and 48 -hour broth cultures of $B$. welchii were filtered (Berkefeld); this filtrate contains quite a little organic acid which increases the speed of the reaction when the serum is added. For example, one rabbit, which had received four injections of $0.1,0.3,0.5,0.5$ c.c. of filtrates, was bled six days after the last injection and the serum contained typical precipitin. When the antiserum was brought in contact with the bacterial filtrate it required approximately 0.25 to 0.5 c.c. of serum to produce a permanent clouding in Io c.c. of filtrate and it required approximately 7 to ro c.c. of filtrate to produce a precipitation in 2.5 c.c. of antiserum. The reaction usually took place in from to to ${ }_{5}$ minutes at room temperature and in 5 to 7 minutes in the incubator. A quantitative estimation of the precipitin, precipitinogen, and precipitate was not made.

\section{ANAPHYLAXIS TO THE PROTEINS OF B. WELCHII.}

Broth cultures of $B$. welchii were grown for several days and precipitated by centrifugalization. The precipitate was then ground in a sterile mortar and $0.01,0.03,0.04,0.05$ and 0.1 c.c. in sterile 0.85 per cent $\mathrm{NaCl}$ solution injected into five guinea-pigs respectively. In 15 days all these guinea-pigs were injected with 1.00 c.c. of a like emulsion in 0.85 per cent $\mathrm{NaCl}$ solution. All showed typical anaphylactic symptoms and one died. Controls injected with corresponding amounts of broth, as well as those receiving one injection of $\mathrm{I}$ c.c. of the emulsion, gave negative results. The relation of anaphylaxis to the partial immunity of the rabbit has not been investigated. It has been determined, however, that the rabbit can be sensitized in the same manner as the guinea-pig to the bacterial protein. 
SUMMARY.

B. welchii shows varying degrees of pathogenicity for rabbits even when no necrotic tissue exists in the body. The bacterium is highly pathogenic for guinea-pigs. Rabbits are far more resistant to infection than guinea-pigs. If necrotic tissue is present in the body $B$. welchii grows rapidly.

Rabbits injected intravenously with cultures of $B$. welchii, immediately killed and incubated for one hour, frequently show evidence of necrosis in the cells around the interlobular veins of the liver, demonstrating the very rapid action of the toxic substance.

$B$. welchii never produces gas in the systemic blood vessels of the body ante mortem. Rapid saccharo-butyric fermentation begins within one hour post mortem in some animals. If necrotic tissue is present in the body, fermentation and gas production may take place at this point at any time during life.

The toxic substances produced by $B$. welchii in dextrose broth cultures are not destroyed completely until the material has been heated to $100^{\circ} \mathrm{C}$. for several hours. Beginning at $70^{\circ} \mathrm{C}$, the toxic substances are volatilized or rendered inert and this takes place rather rapidly at $100^{\circ} \mathrm{C}$. The decrease in the toxicity of the cultures in a measure corresponds to the extent of the volatilization or destruction. The toxic substances are not true bacterial toxins but secretory zymogenic products produced by the bacterial cells capable of generating organic acids. In infections in the body the acids produced act as toxic agents. Butyric acid of the same acidity as the cultures produces the same effect.

No distinct toxin could be isolated from $B$. welchii by the various methods. The organic acids produced increase the protein digestion which goes on in $B$. welchii infections.

Atypical hemolysis is produced by cultures of $B$. welchii and by the serum of rabbits for a short period after they have been injected with the bacterial culture. As organic acids cannot exist free in the blood, this effect of the serum is probably due to formation, by the acids produced, of salts which are not rapidly eliminated. The lytic agent eventually disappears from the blood. The hemolytic action of the cultures is due to the organic acids. Intravascular hemolysis does not occur in animals. 
B. welchii produces leukocytotoxic substances, which also undoubtedly are organic acids.

Opsonins for $B$. welchii are present in normal rabbit serum and may be increased on immunization. Very little phagocytosis occurs unless the bacteria are washed free from organic acids because the organic acids neutralize the opsonins in the serum and cause marked changes in the leukocytes.

Normal and immunized rabbit serum is bactericidal for $B$. welchii. The serum of my animals was most effective in concentrations of amboceptor $0.01-0.005$ c.c. and complement 0.3 c.c. (guinea-pig serum). Normal guinea-pig serum is only slightly destructive for B. welchii when compared with rabbit serum. The phenomenon of "complement deflection" occurs in the bactericidal action of rabbit and guinea-pig sera.

The action of the serum is purely bactericidal. There is no lysis.

Agglutinins develop in the sera of immunized rabbit. In one rabbit the serum agglutinated in a dilution of $I: I 200$, the optimum agglutination occurring at a dilution of $I: 200$ and $I: 500$. The agglutinins after several injections rise to the highest point in the serum about the I 4 th to 2 Ist day, then gradually decline.

Precipitins are developed in the sera of immunized rabbits.

The proteins of $B$. welchii give the anaphylaxis reaction. 